\title{
Subcutaneous interferon alpha 2a combined with cryotherapy vs cryotherapy alone in the treatment of primary anogenital warts: a randomised observer blind placebo controlled study
}

\author{
J M Handley, T Horner, R D Maw, H Lawther, W W Dinsmore
}

\begin{abstract}
Objective-To compare patient tolerance and treatment efficacy of subcutaneous interferon (IFN) alpha 2a plus cryotherapy versus cryotherapy alone in treatment of primary anogenital (AG) warts.

Design-Randomised placebo controlled observer blind study. Statistical analysis was by chi square and Mann Whitney $U$ tests.

Patients -60 patients with newly diagnosed AG warts.

Intervention-29 and 31 patients were treated with subcutaneous IFN alpha 2 a plus cryotherapy or placebo injections plus cryotherapy, respectively.

Main outcome measures-Clinical presence or absence of AG warts. Patients wart-free at 8 weeks were asked to re-attend at 12 weeks; those with persistent warts at 8 weeks were withdrawn from the study.

Results-At 8 weeks $60 \cdot 7 \%$ (17/28 patients) of the IFN group and $67.9 \%$ (19/28 patients) of the placebo group were clinically wart-free (not significant); corresponding figures at 12 week review were $29.6 \%(8 / 27$ patients) and $40 \%$ (10/25 patients) respectively (not significant). There was no difference in treatment response between males and females. Recurrence of warts at three month review, in patients cleared of warts at 8 weeks, was seen in $50 \%$ $(8 / 16)$ and $37 \cdot 5 \%(6 / 16)$ of patients in the IFN and placebo groups respectively (not significant). Multiple warts and the presence of perianal/anal canal warts, either alone or concurrent with warts on the genitalia, at first clinic attendance, were adverse prognostic indicators $(p<0.001$, and $p=0.05$ respec-
\end{abstract}

Department of Genitourinary Medicine, Royal Victoria Hospital, Belfast

J M Handley, T Horner, R D Maw, H Lawther, W W Dinsmore tively). Cervical human papilloma virus (HPV) infection, exophytic or subclinical, was present in $58.3 \%$ and $77 \cdot 2 \%$ of females in the IFN and placebo groups respectively, at trial entry. Although these lesions were not directly treated, colposcopic resolution was seen in $12.5 \%$ of affected women, in both treatment groups, by the end of the 7 week treatment period. Systemic side effects were significantly more common in the IFN than in the placebo group, $50 \%$ versus $10.7 \%$ of patients ( $<<0.01$ ). Severe influenza like symptoms occurred, after the first three injections only, in one patient treated with IFN; all other reported side effects were mild.

Conclusions-Subcutaneous IFN alpha 2a combined with cryotherapy is no more effective than cryotherapy alone in the treatment of primary AG warts. The presence of multiple warts and perianal/anal canal warts are adverse prognostic indicators.

Introduction

Interferon used alone, either topically, intralesionally, or systemically is no more effective than established physical and ablative procedures in the treatment of primary and resistant AG warts. ${ }^{1-26}$

The combination of a physical/chemical ablative procedure with IFN, to treat AG warts is theoretically attractive. The ablative procedure may expose virus particles fragments, and virus infected keratinocytes, to immune and inflammatory cells in the epidermis and upper dermis, stimulating a weak specific/non specific immune response; IFN is an immunostimulant and may augment such a response. In addition IFN may limit local spread of HPV infection by its antiviral and antiproliferative actions. $^{27}$

Thus systemic IFN in combination with a chemical/physical ablative procedure might improve primary clinical cure, and prevent relapse, of AG warts. Few studies using such combination therapy to treat AG warts have been reported; none blind or placebo controlled. ${ }^{722428}$ 
The aims of this study were to compare the clinical response of primary AG warts to systemic IFN in combination with cryotherapy vs cryotherapy alone, to assess patient tolerance to such therapy, and determine if any other factors affect treatment outcome.

\section{Methods}

Ethical considerations

Before undertaking the study approval was obtained from the Medical Ethics Committee, Queens University, Belfast.

\section{Recruitment}

Patients over the age of 16 years were recruited from genitourinary (GU) clinic attenders with newly diagnosed AG warts, and randomly allocated to IFN or placebo treatment groups. Exclusion criteria were previous treatment for AG warts in the preceding 3 years, past or present immunosuppression for any reason, and pregnancy.

\section{Clinical procedure}

Before trial inclusion patients were routinely assessed in the GU clinic, that is clinical examination of the AG tract including proctoscopy, and vaginal speculum in women, rectal, urethral, cervical, and vaginal swabs as appropriate to exclude non specific urethritis (NSU) (diagnosed in males by $>10$ pus cells on a Gram stained anterior urethral swab and a negative culture for $\mathrm{N}$ Gonorrhoeae (GC), non specific genital infection (NSGI) (diagnosed in (1) female sexual partners of males with NSU (2) females with a positive cervical Microtak for Chlamydia trachomatis), infections with $N$ Gonorrhoeae (GC), Gardnerella vaginalis (GV), Trichomonas vaginalis (TV), candida, and a blood sample for syphilis serology. In addition females had colposcopy examination, with biopsy of any abnormal representative areas, and pap smear for cervical cytology. Any other infections detected were appropriately treated before trial entry.

According to treatment group allocation, patients were given subcutaneous IFN alpha $2 \mathrm{a}$, in doses of three million units, or placebo (normal saline), on three separate days in the first week. Thereafter patients had IFN, three million units, or placebo injections, twice weekly, and cryotherapy of AG warts once a week, for the following 6 weeks; a total of 7 weeks treatment in all. Cervical warts/subclinical preneoplasias were not specifically treated.

The study was observer blind. Injections of IFN or placebo were administered by a research nurse (HL), and cryotherapy, clinical and colposcopic assessments were performed independently by one observer $(\mathrm{JH})$. At initial assessment and the 8 week review, patients answered a standardised questionnaire, had an AG tract examination including proctoscopy (application of dilute acetic acid to the external AG regions was not performed), cervical pap smear, and colposcopy examination. At the 3 month review patients had repeat AG tract examina-

Table 1 Demographic data of patients with AG warts treated with interferon plus cryotherapy or cryotherapy alone

\begin{tabular}{|c|c|c|}
\hline & IFN/cryotherapy & Cryotherapy \\
\hline Median no. of warts & 10 & 13 \\
\hline Median area of wart tissue (square $\mathrm{cm}$ ) & 2 & 2 \\
\hline \multicolumn{3}{|l|}{ Site of warts (\% of patients) } \\
\hline $\begin{array}{l}\text { MALES } \\
\text { 1. inner prepuce/glans/coronal sulcus } \\
\text { 2. outer prepuce/penile shaft } \\
\text { 3. terminal urethra } \\
\text { 4. perianal/anal canal }\end{array}$ & $\begin{array}{l}40 \\
20 \\
14 \cdot 3 \\
14 \cdot 3\end{array}$ & $\begin{array}{l}44 \cdot 4 \\
22 \cdot 2 \\
22 \cdot 2 \\
44 \cdot 4\end{array}$ \\
\hline $\begin{array}{l}\text { FEMALES } \\
\text { 1. introitus } \\
\text { 2. vulva } \\
\text { 3. vaginal } \\
\text { 4. perianal/anal canal }\end{array}$ & $\begin{array}{c}28 \cdot 6 \\
71 \cdot 4 \\
0 \\
50\end{array}$ & $\begin{array}{r}27 \cdot 2 \\
77 \cdot 2 \\
7 \cdot 1 \\
68 \cdot 2\end{array}$ \\
\hline $\begin{array}{l}\text { Morphological wart type ( } \% \text { of patients }) \text { : } \\
\text { 1. hyperplastic } \\
\text { 2. sessile } \\
\text { 3. mixture of } 1 / 2\end{array}$ & $\begin{array}{r}86 \cdot 2 \\
13 \cdot 7 \\
6 \cdot 9\end{array}$ & $\begin{array}{r}77 \cdot 4 \\
22 \cdot 5 \\
9 \cdot 6\end{array}$ \\
\hline $\begin{array}{l}\text { Male sexual behaviour (no. of patients): } \\
\text { 1. heterosexual } \\
\text { 2. homosexual } \\
\text { TOTAL }\end{array}$ & $\begin{array}{r}14 \\
1 \\
15\end{array}$ & $\begin{array}{l}9 \\
0 \\
9\end{array}$ \\
\hline $\begin{array}{l}\text { Female sexual behaviour (no. of patients): } \\
\text { 1. heterosexual } \\
\text { 2. virgin } \\
\text { TOTAL }\end{array}$ & $\begin{array}{r}13 \\
1 \\
14\end{array}$ & $\begin{array}{r}22 \\
0 \\
22\end{array}$ \\
\hline Total no. of patients & 29 & 31 \\
\hline
\end{tabular}


Table 2 Prevalence of $A G$ warts at eight week review in patients treated with IFN plus cryotherapy and cryotherapy alone

\begin{tabular}{lll}
\hline & \multicolumn{2}{l}{ No. of patients } \\
\cline { 2 - 3 } & $\begin{array}{ll}\text { IFN/ } \\
\text { cryotherapy }\end{array}$ & $\begin{array}{l}\text { Placebo/ } \\
\text { cryotherapy }\end{array}$ \\
\hline Clinical cure & $17(60 \cdot 7 \%)$ & $19(67 \cdot 9 \%)$ \\
Persistent warts & 11 & 9 \\
Dropouts & 1 & 3 \\
Total (excluding dropouts) & $28(100 \%)$ & $28(100 \%)$ \\
\hline
\end{tabular}

tion with proctoscopy. All biopsy and cytology specimens were analysed in routine cytology and histopathology laboratories.

Cryotherapy was performed with a standard cryoprobe, after prior application of $\mathrm{KY}$ jelly to the wart(s), for a single 60 second freeze. When required local anaesthetic cream (EMLA) was applied instead of KY gel. Patients were instructed to bathe in saline twice daily, until healing of treated areas was complete.

At 8 week review patients clinically clear of AG warts were asked to re attend a further four to six weeks later; those who had persistent warts at 8 weeks were withdrawn from the study. During the study period patients were advised either to avoid sexual intercourse, or to use condoms during intercourse.

\section{Results}

Demographic data

Twenty nine patients were included in the IFN group, and 31 in the placebo group. There were no significant demographic differences between patients in the two treatment groups (table 1).

\section{Treatment efficacy}

Four patients, one in the IFN and three in the placebo group, failed to complete the 7 week treatment course. Three were withdrawn because they
Table 3 Prevalence of $A G$ warts at three month review in patients treated with IFN plus cryotherapy and cryotherapy alone

\begin{tabular}{lll}
\hline & \multicolumn{2}{l}{ No. of patients } \\
\cline { 2 - 3 } & $\begin{array}{l}\text { IFN/ } \\
\text { cryotherapy }\end{array}$ & $\begin{array}{l}\text { Placebo/ } \\
\text { cryotherapy }\end{array}$ \\
\hline Clinical cure & $8(29 \cdot 6 \%)$ & $10(40 \%)$ \\
Persistent warts & $19(70 \cdot 4 \%)$ & $15(60 \%)$ \\
$\begin{array}{l}\text { a. withdrawn at 8 weeks } \\
\text { b. recurrence after cure }\end{array}$ & 11 & 9 \\
$\quad$ at 8 weeks & 8 & 6 \\
Dropouts & 2 & 6 \\
Total (excluding dropouts) & $27(100 \%)$ & $25(100 \%)$ \\
\hline
\end{tabular}

missed two treatment sessions; one was withdrawn because of pregnancy. No patient dropped out or was withdrawn because of side effects.

Table 2 shows results at eight week review. There was no significant difference in overall clinical response between the two treatment groups, or between males and females within each treatment group.

Of 17 and 19 patients clinically clear of warts at 8 weeks in the IFN and placebo treatment groups respectively, 16 in both groups reattended for 3 month review. Recurrence of warts was seen in $50 \%$ $(8 / 16)$ of patients in the IFN group, and $37.5 \%(6 / 16)$ patients in the placebo group. There was no significant difference in clinical response at three month review between the treatment groups (table 3 ). These figures were calculated assuming patients withdrawn with persistent warts at 8 weeks, would still have had their warts at 3 months without further treatment in the intervening period.

Resolution of cervical lesions was seen in $1 / 8$ patients in the IFN group, and 2/16 patients in the placebo group.

Tables 4 and 5 summarise the importance of other factors in determining treatment outcome. The presence of multiple warts (Mann Whitney U $\mathrm{p}<0.001$ ), and perianal/anal canal warts (chi square

Table 4 Factors determining outcome at 8 week review in patients with primary AG warts treated with IFN plus cryotherapy and cryotherapy alone

\begin{tabular}{|c|c|c|c|}
\hline & $\begin{array}{l}\text { No. of patients cured } \\
\text { of warts at } 8 \text { week review }\end{array}$ & & $\begin{array}{l}\text { Significance (p) } \\
\text { (Chi square) }\end{array}$ \\
\hline 1. Sex & $\begin{array}{l}\text { male } \\
\text { female }\end{array}$ & $\begin{array}{l}17 / 23 \\
19 / 33\end{array}$ & NS \\
\hline 2. Other AG tract infection at 1 st visit & $\begin{array}{l}\text { present } \\
\text { none }\end{array}$ & $\begin{array}{l}19 / 32 \\
17 / 24\end{array}$ & NS \\
\hline 3. Site of warts & $\begin{array}{l}\text { genital only } \\
\text { gen }+ \text { perianal/perianal only }\end{array}$ & $\begin{array}{l}24 / 30 \\
12 / 26\end{array}$ & 0.05 \\
\hline 4. Cervical warts virus infection at 1 st visit & $\begin{array}{l}\text { present } \\
\text { none }\end{array}$ & $\begin{array}{c}13 / 22 \\
4 / 9\end{array}$ & NS \\
\hline 5. Protected Int. during treatment & $\begin{array}{l}\text { yes } \\
\text { no int. }\end{array}$ & $\begin{array}{l}20 / 35 \\
16 / 21\end{array}$ & NS \\
\hline 6. Unprotected int. during treatment & $\begin{array}{l}\text { yes } \\
\text { none }\end{array}$ & $\begin{array}{c}3 / 5 \\
33 / 51\end{array}$ & NS \\
\hline
\end{tabular}


Table 5 Importance of number, area, and duration of AG warts in determination of outcome at 8 eight week review in patients treated with IFN plus cryotherapy and cryotherapy alone

\begin{tabular}{|c|c|c|c|}
\hline & \multicolumn{2}{|l|}{ Patients } & \multirow[b]{2}{*}{ p values } \\
\hline & free of warts & persistent warts & \\
\hline No. warts at first visit (median/range) & $7 / 1-25$ & $16 / 6-26$ & $<0.001$ \\
\hline Area of wart tissue (square $\mathrm{cm}$ ) (median/range) & $1 / 1-3$ & $1 / 1-3$ & NS \\
\hline Wart duration prior to first visit (months, median/range) & $2 / 0-36$ & $2 / 0-36$ & NS \\
\hline No. of patients & 36 & 20 & \\
\hline
\end{tabular}

$p=0.05)$, at trial entry, were associated with significantly worse prognosis.

\section{Side effects}

Side effects of cryotherapy were local irritation, blistering, and ulceration. These were generally well tolerated and resolved within 7 to 10 days. No secondary infection necessitating treatment occurred.

Systemic side effects were reported significantly more frequently in the IFN/cryotherapy group (chi squared $\mathrm{p}<0.01$ ). (table 6 ). In the IFN/cryo group fever like symptoms occurred within 24 hours following injection, usually only after the first two to three injections. Headache and fatigue were reported both directly after injection and continuously, apparently unrelated to injections. With the exception of one male patient who experienced severe fever, myalgia and nausea which necessitated bed rest for 48 hours after the first IFN injection, all other reported side effects were mild. No patient stopped therapy or was withdrawn from the study because of side effects.

\section{Discussion}

Although this study was of a small number of patients with relatively short post treatment follow up, the

Table 6 Systemic side effects reported during study period in patients with $A G$ warts treated with IFN plus cryotherapy and cryotherapy alone

\begin{tabular}{lll}
\hline & \multicolumn{2}{l}{ No. of patients } \\
\cline { 2 - 3 } & $\begin{array}{l}\text { IFN/ } \\
\text { cryotherapy }\end{array}$ & $\begin{array}{l}\text { Placebo/ } \\
\text { cryotherapy }\end{array}$ \\
\hline Fever post injection & 8 & 2 \\
Headache & 3 & 1 \\
Fatigue & 1 & 1 \\
Myalgia & 2 & 0 \\
Foul taste in mouth & 1 & 0 \\
Stomach cramps & 1 & 0 \\
Mood disturbance & 0 & 1 \\
Total no. patients with & 14 & $3^{\star}$ \\
$\quad$ systemic side effects & 14 & \\
Total no. patients & & 28 \\
completing treatment & 28 & \\
\hline *chi square p < $0 \cdot 01$. & &
\end{tabular}

results provide no evidence to suggest systemic IFN combined with cryotherapy is more effective than cryotherapy alone in the treatment of AG warts. Three month figures reported in this study based on the assumption no warts present on completion of treatment are likely to regress in the following four to six weeks, either spontaneously or through residual effects of treatment, may slightly underestimate true clinical response at this time.

A possible explanation for our findings is lack of exposure of HPV infected keratinocytes within warts to concentrations of IFN high enough to (1) stimulate an effective specfic immune response against either intracellular HPV or viral related antigen expressed on the surface of infected cells (2) prevent intracellular viral replication and transcription.

The relative lack of side effects seen in IFN treated patients in this study, should enable a similar study using higher doses of IFN to be undertaken. However, evidence from studies treating AG warts with IFN alone, suggests increasing doses of IFN, to a maximum limited by side effects, does not significantly improve treatment efficacy. ${ }^{19} 2029$

Few studies using IFN in combination with other modalities are reported. Only a minority of these studies directly compare combinaton therapy with the relevant single established treatment; none of these studies are placebo controlled. ${ }^{222428}$

One study reported clinical cure of $51 \%$ of warts treated with intralesional IFN and cryotherapy vs $15 \%$ of warts treated by cryotherapy alone. ${ }^{7}$

Other comparative studies report $90 \%$ cure of warts treated with IFN plus electrocoagulation vs $80 \%$ cure of warts treated with electrocoagulation alone. ${ }^{24}$ Intralesional IFN plus podophyllin gave rates of $67 \%$ cure of treated warts vs $43 \%$ cure of warts treated with podophyllin alone, ${ }^{7}$ and a study comparing patients with warts treated with subcutaneous IFN plus podophyllin, podophyllin alone, and IFN alone, reported clinical cure in $31 \%, 11 \%$, and $28 \%$ of patients respectively. ${ }^{22}$ Bichloracetic acid (BCA) plus IFN was superior to BCA alone in treatment of AG warts. ${ }^{28}$

Cure rates of $95 \%$ in patients with warts treated by intralesional IFN followed by laser ablation, and 
$87.5 \%$ in patients treated with intramuscular IFN plus laser ablation are reported. ${ }^{28}$

All these studies must be interpreted in light of reported efficacy of single agent therapy of AG warts; laser ablation $65-97 \%$ clinical cure after a single treatment, ${ }^{30-37}$ electrocautery/coagulation $71-90 \%$ clinical cure after a single treatment, ${ }^{24-42}$ cryotherapy $55-100 \%$ cure after repeated treatments ${ }^{43-47}$ podophyllin $22-76 \%$ cure after treatment courses. ${ }^{39}$ 48-54

It has been suggested IFN combination therapy may lower the recurrence rate in patients clinically cleared of warts by chemical/surgical modalities. Recurrence after most surgical procedures is estimated around $10-15 \%$, and between $0-69 \%$ for podophyllin treated lesions. ${ }^{3949052-54}$ Our results do not support this assumption.

In conclusion our findings suggest IFN plus cryotherapy is no more effective than cryotherapy alone in treatment of primary AG warts; adverse clinical prognostic factors are multiple warts and presence of warts in the perianal/anal canal regions.

Funding for purchase of interferon alpha 2a (Roferon) was supplied by Roche Products (UK) Ltd.

This work was supported by a Royal Victoria Hospital Research Fellowship awarded to J Handley for the year $1989 / 90$.

Address for correspondence: Dr J Handley, Department of Dermatology, Royal Victoria Hospital, Belfast, N Ireland BT12 6BA.

1 Zwiorek L, Schmidt-Rhode $P$, Schulz KD. Interferon in the treatment of condylomata acuminata. Geburtschilfe Frauenheilkd 1989;49:1001-5.

2 Ikic D, Bosnic N, Smerdal S, Jusic D, Soos E, Delimar N. A double blind clinical study with human leukocyte interferon in the therapy of condylomata acuminata. Yugo Acad Sci Arts (Zagreb) 1975:229-34.

3 Tyring SK. Treatment of condyloma acuminatum with interferon. Semin Oncol 1988;15(5 suppl 5):35-40.

4 Corwin Vance J, Bart BJ, Hansen RC. Intralesinal recombinant alpha two interferon for the treatment of patients with condylomata or verruca plantaris. Arch Dermatol 1986; 122:272-7.

5 Welander CE, Homesley HD, Smiles KA, Peets EA. Intralesional interferon alpha two $b$ for the treatment of genital warts. Am J Obstet Gynecol 1990;162:348-54.

6 Eron LJ, Judson F, Tucker S, et al. Interferon therapy for condylomata acuminata. N Engl J Med 1986;315:1059-64.

7 Clinicians Workshop. Intron $A$ in the treatment of condylomata acuminata. In: conference proceedings: Interferon and condyloma acuminatum. Royal Soc Med (London) 1988.

8 Maw RD, Dinsmore WW, Paavonen J, et al. A european multicentre open study of treatment on condylomata acuminata using podophyllin $25 \%$ versus alpha 2 interferon subcutaneously. In: conference proceedings. International Congress on Sexually Transmitted Diseases. Amsterdam 1989.

9 Benedetti-Pannicci P, Scambia G, Baochhi G, Perrone L, Pintus C, Mancusco S. Randomised clinical trial comparing systemic interferon with diathermocoagulation in primary multiple and widespread anogenital condylomata. Obstet Gynecol 1989;74:393-7.
10 Schonfield A, Schattner A, Orespi M, et al. Intramuscular human interferon beta injections in treatment of condylomata acuminata. Lancet 1984; i:1038-42.

11 Fierlbeck G, Schiebel U, Muller C. Immunohistology of genital warts in different stages of regression after therapy with interferon gamma. Dermatlogica 1989;179:191-5.

12 Schneider A, Papendick U, Gissmann L, De Villiers EM. Interferon treatment of human genital papilloma virus infection: importance of viral type. Int J Cancer 1987;40:610-4.

13 Keay S, Teng N, Eisenberg M, Story B, Sellers PW, Merigan TC. Topical interferon for treating condyloma acuminata in women. J Inf Dis 1988;158:934-9.

14 Friedman-Kien AE, Eron LJ, Conant M, et al. Natural interferon alpha for treatment of condylomata acuminata. $J A M A$ 1988;259:533-8.

15 Boot JM, Blog FB, Stolz E. Intralesional interferon alpha two b treatment of condylomata acuminata previously resistant to podophyllin resin application. Genitourin Med 1989;65:50-3.

16 Reichman RC, Oakes D, Bonnez W, et al. Treatment of condyloma acuminatum with three different interferons administered intralesionally. Ann Int Med 1988;108:675-9.

17 Hatch K, Bart B, Hansen R, Millikan L, Reichman R, Berman B. Evaluation of interferon alpha two in the treatment of condyloma acuminata. In: conference proceedings, $14 \mathrm{th}$ International Congress on Chemotherapy. Kyotb, Japan 1985.

18 Geffen JR, Klein RJ, Friedman-Kien AE. Intralesional administration of large doses of human leukocyte interferon for the treatment of condylomata acuminata. J Inf Dis 1984;150: $612-5$.

19 Gross G, Ikenberg H, Roussaki A, Drees N, Schopf E. Systemic treatment of condylomata acuminnata with recombinant interferon alpha 2a: low dose superior to high dose regime. Chemother 1986;32:537-41.

20 Kirby PK, Kiviat N, Beckman A, Wells D, Sherwin S, Corey L. Tolerance and efficacy of recombinant human interferon gamma in the treatment of refractory genital warts. $A m \mathrm{~J} \mathrm{Med}$ $1988 ; 85: 183-8$.

21 Gall SA, Hughes CE, Trofatter K. Interferon for the therapy of condyloma acuminatum. Am J Obstet Gynecol 1985;153: $157-63$.

22 Weck PC, Buddin DA, Whisnant JK. Interferons in the treatment of genital HPV infections. Am J Med 1988; 85(suppl 2a): 159-64.

23 Olsen EA, Trofatter KF, Gall SA, et al. Human lymphoblastoid alpha interferon in the treatment of refractory condylomata. $J$ Invest Dermatol 1985;84:359-64.

24 Piccoli R, Santoro MG, Nappi C, et al. Vulvovaginal condylomatosis and relapse: Combined treatment with electrocauterisation and beta interferon. Clip Exp Obstet Gynecol 1989;16:30-5.

25 Gross G, Roussaki A, Schopf E, et al. Successful treatment of condylomata acuminata and bowenoid papulosis with subcutaneous injections of low dose recombinant interferon alpha. Arch Dermatol 1986;122:749-50.

26 Olsen EA, Kelly FF, Vollmer RT, Buddin DA, Weck PC Comparative study of systemic interferon alpha N1 and isotretinoin in the treatment of resistant condylomata acuminata. J Am Acad Dermatol 1989;20:1023-30.

27 Trofatter K. Interferon. Obstet Gynecol Clin N Amer 1987; 14:569-79.

28 Hatch KD. Interferon treatment of human papilloma virus. Colposcopist 1989;21:1-3.

29 Reichman RC, Micha JP, Weck PC, et al. Interferon alpha N1 for refractory genital warts: efficacy and tolerance of low dose systemic therapy. Antiviral Res 1988;10:41-57.

30 Ferenczy A. Comparison of 5 fluorouracil and carbon dioxide laser for the treatment of vaginal condylomata. Obstet Gynecol 1984;64:773-8.

31 Baggish MS. Improved laser techniques for the elimination of genital and extragenital warts. Am J Obstet Gynecol 1985; 153:545-50.

32 Tuero JG, Lacort LP, Justo AI, et al. Tratamiento de condilomas acuminados externos mediante laser de neodimio-YAG. Arch Esp de Virol 1988;41:93-7.

33 Bellina $\mathrm{JH}$. The use of $\mathrm{CO} 2$ laser in the management of condyloma acuminatum with eight year follow up. Am J Obstet Gynecol 1983;147:375-8.

34 Reid R, Stanhope CR, Herschman BR, et al. Genital warts and cervical cancer. Cancer 1982;50:377-87.

35 Ferenczy A. Treating genital condyloma during pregnancy with $\mathrm{CO} 2$ laser. Am J Obstet Gynecol 1984;148:9-12.

36 Kryger-Baggeson N, Larsen JF, Pedersen PH. $\mathrm{CO} 2$ laser treatment of condylomata acuminata. Acta Obstet Gynecol 
Scand 1984;63:341-3.

37 Baggish MS. Treating viral venereal infections with the $\mathrm{CO} 2$ laser. J Reprod Med 1982;27:737-42.

38 Von Gunhild B. Lokale behandlung der cervikalen intraepithelialen neoplasie mit einer 5\% igen 5FU. Zentrable Gynakol 1987;109:1510-6.

39 Jensen SL. Comparison of podophyllin application with simple surgical excision in clearance and recurrence of perianal condylomata. Lancet 1985;1:1146-8.

40 Simmons PD, Langlet F, Thin RNT. Cryotherapy versus electrocautery in the treatment of genital warts. $B r J$ Veneral Dis $1981 ; 57: 273-4$.

41 Bekassy $Z$, Westrom $L$. Infrared coagulation in the treatment of condyloma acuminata in the female genital tract. Sex Transm Dis 1987;14:209-12.

42 Graber EA, Barber HRK, O'Rourke JS. Simple surgical treatment for condyloma acuminata of the vulva. Obstet Gynecol 1967;29:247-50.

43 Ghosh AK. Cryosurgery of genital warts in women in which podophyllin treatment failed or was contraindicated. $\mathrm{Br}$ Venerael Dis 1977;53:49-53.

44 Balsdon MA. Cryosurgery of genital warts. $\mathrm{Br} J$ Venereal Dis 1978;54:352-3.

45 Bashi SA. Cryotherapy versus podophyllin in the treatment of genital warts. Int J Dermatol 1985;24:535-6.

46 Dodi G, Infantino A, Moretti R, Scalco G, Lise M. Cryotherapy of anorectal warts and condylomata. Cryobiol 1982;19:287-8.
47 Ong TK, $\mathrm{Ng}$ CSA, Ratnam SS. Treatment of genital warts by cryosurgery-a follow up study. Ann Acad Med 1980;9: 396-8.

48 Clark DP. Condyloma acuminatum. Dermatol Clin 1987;5: 779-88.

49 Von Krogh G. Topical treatment of penile condylomata acuminata with podophyllin, podophyllotoxin, and colchicine. Acta Derm Venereol Stockh 1978;58:163-8.

50 Simmons PD. Podophyllin $10 \%$ and $25 \%$ in the treatment of anogenital warts: a comparative double blind study. $\mathrm{Br} J$ Veneral Dis 1981;57:208-9.

51 Maiti H, Haye KR. Self treatment of condylomata acuminata with podophyllin resin. Practitioner 1985;229:37-9.

52 Stone KM, Becker TM, Hadgu A, Kraus SJ. Treatment of external genital warts: a randomised clinical trial comparing podophyllin, cryotherapy, and electrodessication. Genitourin Med 1990;66:16-9.

53 Von Krogh G. Condylomata acuminata 1983: an updated review. Sem Dermatol 1983;2:109-29.

54 Peterson SC, Worm AM, Kroon S, Tikjob G. Podophyllotoxin $5 \%$ and podophyllin $20 \%$ in the treatment of anogenita warts: a comparative double blind study. Eur J Sex Transm Dis 1985;2:155-8.

Accepted for publication 17 May 1991 